\title{
Pelaksanaan Lelang Eksekusi Hak Tanggungan Melalui Media Internet Masa Pandemi Covid-19 Berdasarkan Undang-Undang Informasi Dan Transaksi Elektronik (Studi Pada KPKNL Medan)
}

\author{
Implementation of Liability Execution Auction Through Internet Media \\ for the Pandemic Time of Covid-19 Based on Law of Information and \\ Electronic Transactions (Study on Medan KPKNL) \\ Maryoso, Isnaini \& M. Citra Ramadhan \\ Program Studi Magister Ilmu Hukum, Universitas Medan Area, Indonesia \\ Diterima: 03 Mei 2021 Direview: 03 Mei 2021; Disetujui: 20 September 2021 \\ *Coresponding Email:mangido@gmail.com
}

\begin{abstract}
Abstrak
Pandemi Covid-19 secara nyata berdampak pada sektor ekonomi, khususnya kalangan perbankan dalam memperoleh pelunasan hutang dari debitur. Untuk memperoleh pelunasan hutang dari debitur wanprestasi dapat dilakukan dengan menjual jaminan hutang yang telah diikat Hak Tanggungan. Penelitian ini bertujuan untuk mengkaji dan menganalisis aturan hukum, mekanisme dan hambatan yang dihadapi dalam pelaksanaan lelang eksekusi Hak Tanggungan melalui media internet masa pandemi Covid-19 berdasarkan undang-undang ITE. Penelitian ini menggunakan metode penelitian hukum yuridis normatif dengan pendekatan hukum secara historis, eksplanatoris dan sinkronisasi dengan menggunakan bahan hukum primer, sekunder dan tersier kemudian analisis data dilakukan secara kualitatif. Hasil penelitian menunjukkan pelaksanaan lelang eksekusi Hak Tanggungan melalui media internet masa pandemi Covid-19 berdasarkan undang-undang ITE pada KPKNL Medan telah dilaksanakan berdasarkan hukum yang berlaku dan Risalah lelang yang dihasilkan merupakan akte otentik yang sah. Namun demikian, masih perlu diupayakan perbaikan baik dari segi peraturan maupun sistem pendukungnya agar pelaksanaan lelang melalui internet dapat dilaksanakan secara efektif, transparan, akuntabel, adil, dan menjamin kepastian hukum.

Kata kunci: Masa Covid-19; Lelang; Media Internet; Eksekusi; Hak Tanggungan.
\end{abstract}

\begin{abstract}
The Covid-19 pandemic has significantly impacted the economic sector, especially the banking sector in obtaining debt repayments from debtors. To obtain debt repayment from a defaulting debtor, it can be done by selling debt guarantees that have been tied with Mortgage Rights. This study aims to examine and analyze the legal rules, mechanisms and obstacles faced in the implementation of the Mortgage Execution auction through the internet media during the Covid19 pandemic based on the ITE law. This study uses a normative juridical legal research method with a historical, explanatory and synchronization legal approach using primary, secondary and tertiary legal materials then data analysis is carried out qualitatively. The results of the study show that the auction of Mortgage executions through the internet media during the Covid-19 pandemic based on the ITE law at the Medan KPKNL has been carried out based on applicable law and the resulting auction minutes are valid authentic deeds. However, it is still necessary to improve both in terms of regulations and support systems so that auctions via the internet can be carried out effectively, transparently, accountable, fair, and guarantee legal certainty.
\end{abstract}

Keywords: Covid-19 Period; Auction; Internet Media; Execution; Mortgage Rights.

How to Cite: Maryoso, Isnaini, \& Ramadhan, M.C. (2021). Pelaksanaan Lelang Eksekusi Hak Tanggungan Melalui Media Internet Masa Pandemi Covid-19 Berdasarkan Undang-Undang Informasi Dan Transaksi Elektronik (Studi Pada KPKNL Medan). Journal of Education, Humaniora and Social Sciences (JEHSS). 4 (2): 616-628. 


\section{PENDAHULUAN}

Penyebaran Covid-19 di Indonesia sempat melumpuhkan beberapa sektor perekonomian tidak terkecuali sektor perbankan (Muchlis, n.d.). Kebijakan pemerintah untuk menerapkan Pembatasan Sosial Berskala Besar (PSBB) serta pemberian restrukturisasi kredit pada sektor perbankan berdampak pada tingginya kredit macet yang dialami oleh sektor perbankan.

Kredit yang tidak dilunasi sesuai waktu yang telah ditentukan akan menjadi kredit bermasalah atau non performing loan yang akan mempengaruhi likuiditas bank yang bersangkutan. Jika hal ini terjadi dalam skala luas maka akan mempengaruhi perekonomian negara secara keseluruhan (Abdul, 2004).

Bank memerlukan jaminan agar dapat memperoleh returns yaitu hasil yang akan dicapai dari kegiatan yang mendapatkan pembiayaan tersebut. Jaminan terdiri dari jaminan umum, yaitu jaminan yang diberikan bagi semua kreditur dan menyangkut semua harta kekayaan debitur dan jaminan khusus, yaitu benda-benda tertentu yang ditunjuk secara khusus sebagai jaminan piutang dan hanya berlaku bagi kreditur tertentu. Jaminan khusus timbul karena adanya perjanjian yang khusus diadakan antara kreditur dan debitur.

Menurut sifatnya, jaminan dapat berupa jaminan perorangan atau jaminan pribadi dan jaminan kebendaan. Jaminan perorangan atau jaminan pribadi (personal guaranty), yaitu jaminan seseorang pihak ketiga yang bertindak untuk menjamin dipenuhinya kewajiban-kewajiban debitur. Jaminan kebendaan merupakan jaminan berupa hak mutlak atas sesuatu benda untuk menjamin pelunasan utang tertentu. Jaminan yang ideal adalah jaminan yang dapat dengan mudah membantu perolehan kredit akan tetapi tidak melemahkan potensi kekuatan si penerima kredit dalam menjalankan usahanya dan mudah diuangkan untuk melunasi utang debitur apabila debitur tersebut wanprestasi.

Lembaga jaminan diperlukan untuk memberikan kepastian hukum, memberi manfaat dan keadilan baik bagi pemberi kredit maupun penerima kredit dan memberikan rasa keadilan bagi para pihak (Marliyana, 2019). Pemerintah telah menyediakan pedoman peraturan lembaga penjaminan, diantaranya adalah Undang-Undang Nomor 4 Tahun 1996 tentang Hak Tanggungan Atas Tanah Beserta Benda-Benda Yang Berkaitan Dengan Tanah.

Hak Tanggungan merupakan jaminan khusus sebagaimana diatur dalam Pasal $1132 \mathrm{KUH}$ Perdata, yang dapat memberikan kepastian kepada kreditur serta memperkuat kedudukan kreditur apabila terdapat lebih dari satu kreditur. Kreditur tersebut mempunyai hak preferent, yaitu hak untuk didahulukan di atas kreditur-kreditur lainnya dalam pemenuhan hutang debitur. Asas ini dikenal dengan nama droit de preference, yaitu hak mendahului yang dimiliki kreditur atas benda-benda tertentu yang dijaminkan pada kreditur tersebut (Sulastri, 2016).

Hak Tanggungan bersifat accesoir, yaitu merupakan perjanjian tambahan yang melekat pada perjanjian pokoknya yaitu perjanjian utang piutang. Apabila perjanjian pokoknya telah hapus maka hapus pula Hak Tanggungan yang melekat di atas jaminan kebendaannya akan tetapi apabila debitor cidera janji, maka pemegang Hak Tanggungan pertama mempunyai hak untuk menjual obyek Hak Tanggungan atas kekuasaan sendiri melalui pelelangan umum serta mengambil pelunasan piutangnya dari hasil penjualan tersebut. (Wijaya dkk, 2020)

Berdasarkan ketentuan Pasal 6 Undang-Undang Hak Tanggungan, apabila debitor cidera janji, Kreditur Pemegang Hak Tanggungan pertama atas kekuasaannya sendiri berhak untuk menjual objek Hak Tanggungan melalui pelelangan umum (parate executie) (Risa, 2017). Kreditur pemegang Hak Tanggungan pertama dapat secara langsung mengajukan permohonan lelang ke Kantor Pelayanan Kekayaan Negara dan Lelang (KPKNL) sesuai dengan wilayah kerjanya.

Lelang adalah penjualan barang yang terbuka untuk umum, dengan penawaran harga secara tertulis dan/atau lisan yang semakin meningkat atau menurun untuk mencapai harga tertinggi, yang didahului dengan pengumuman lelang (Zaki, 2016). Penjualan lelang memiliki karakteristik sendiri namun tetap mengacu pada ketentuan Kitab Undang-Undang Hukum Perdata mengenai jual beli. Pasal 1457 Kitab Undang-Undang Hukum Perdata merumuskan bahwa jual beli adalah suatu persetujuan dengan mana pihak satu mengikatkan dirinya untuk menyerahkan suatu kebendaan, dan pihak lain untuk membayar harga yang dijanjikan. Lelang mengandung unsurunsur yang tercantum dalam definisi jual beli, yaitu adanya subjek hukum yaitu penjual dan pembeli, adanya kesepakatan antar penjual dan pembeli tentang barang dan harga, dan adanya wwith http://mahesainstitute.web.id/ojs2/index.php/jehss 
Maryoso, Isnaini \& M. Citra Ramadhan, Pelaksanaan Lelang Eksekusi Hak Tanggungan

kewajiban yang timbul antara pihak penjual dan pembeli (Amalia, 2019). Lelang adalah jual beli dalam bentuk khusus. Lelang termasuk perjanjian jual beli barang sehingga dalam pelaksanaan lelang berlaku pula syarat-syarat sahnya perjanjian sebagaimana diatur dalam Pasal 1320 Kitab Undang-Undang Hukum Perdata (Subekti:2005).

Seiring dengan globalisasi ekonomi dan meningkatnya laju perkembangan teknologi informasi saat ini, pelaksanaan lelang mengalami modernisasi dengan adanya pelaksanaan lelang melalui internet. Pelaksanaan lelang melalui internet dilakukan untuk meningkatkan kualitas pelayanan lelang kepada pengguna jasa lelang. Pelaksanaan lelang melalui internet dapat dilaksanakan untuk jenis lelang eksekusi maupun non eksekusi, termasuk jenis lelang eksekusi Hak Tanggungan berdasarkan Undang-Undang Hak Tanggungan. Penggunaan media internet memberikan kesempatan kepada peserta lelang untuk mengikuti lelang dimana pun mereka berada dan tidak perlu hadir secara fisik di tempat pelaksanaan lelang. (Ferry dkk, 2019)

Indonesia merupakan negara yang berdasarkan atas hukum maka penggunaan atau pemanfaatan teknologi internet juga harus dilaksanakan berdasarkan hukum. Pelaksanaan lelang melalui internet dalam rangka eksekusi Hak Tanggungan dilakukan berdasarkan Undang-Undang Informasi dan Transaksi Elektronik Nomor 11 tahun 2008 tentang Informasi dan Transaksi Elektronik (ITE) sebagaimana telah diubah oleh Undang-Undang Nomor 19 Tahun 2016 tentang Perubahan Atas Undang-Undang Nomor 11 Tahun 2008 tentang Informasi Dan Transaksi Elektronik. (Saifudin, 2019)

Pasal 1 Undang-Undang Nomor 11 tahun 2008 menjelaskan bahwa Informasi Elektronik yang dibuat, diteruskan, dikirimkan, diterima, atau disimpan dalam bentuk analog, digital, elektromagnetik, optikal, atau sejenisnya, yang dapat dilihat, ditampilkan, dan/atau didengar melalui Komputer atau Sistem Elektronik, termasuk tetapi tidak terbatas pada tulisan, suara, gambar, peta, rancangan, foto atau sejenisnya, huruf, tanda, angka, Kode Akses, simbol atau perforasi yang memiliki makna atau arti atau dapat dipahami oleh orang yang mampu memahaminya. Pasal 5 ayat 1 Undang-Undang Nomor 11 tahun 2008 menyatakan bahwa Informasi Elektronik dan/atau Dokumen Elektronik dan/atau hasil cetaknya merupakan alat bukti hukum yang sah sedangkan dalam Pasal 17 Undang-Undang tersebut menyatakan bahwa penyelenggaraan transaksi elektronik dapat dilakukan dalam lingkup publik maupun privat. Undang-Undang ini memberikan peluang terhadap pemanfaatan Teknologi Informasi oleh penyelenggara negara, orang, Badan Usaha, dan/atau masyarakat. Peluang ini dimanfaatkan oleh Direktorat Jenderal Kekayaan Negara untuk memberikan pelayanan lelang dengan memanfaatkan media internet. Pengaturan pelaksanaan lelang melalui internet secara rinci diatur dalam Peraturan Menteri Keuangan Nomor 90/PMK.06/2016 tentang Pedoman Pelaksanaan Lelang dengan Penawaran Secara Tertulis Tanpa Kehadiran Peserta Lelang Melalui Internet dan Peraturan Menteri Keuangan Nomor 27/PMK.06/2016 tentang petunjuk pelaksanaan lelang.

Pelaksanaan lelang melalui internet dalam rangka eksekusi Hak Tanggungan berdasarkan Undang-Undang Informasi Dan Transaksi Elektronik diselenggarakan di Kantor Pelayanan Kekayaan Negara dan Lelang (KPKNL) dan di hadapan Pejabat Lelang dari KPKNL. Pejabat lelang bertugas untuk mempersiapkan dan melaksanakan lelang serta membuat berita acara pelaksanaan lelang yang disebut dengan Risalah Lelang. Risalah Lelang merupakan bukti autentik pelaksanaan lelang. Risalah lelang merupakan bukti bagi penjual yang telah melaksanakan lelang dan bagi pembeli sebagai akta jual beli dan sebagai dasar melakukan balik nama untuk memperoleh hak atas tanah/objek Hak Tanggungan yang telah dibelinya.

Pelaksanaan lelang eksekusi Hak Tanggungan pada masa Covid 19 melalui media internet berdasarkan Undang-Undang Informasi dan Transaksi Elektronik harus dilaksanakan dengan landasan hukum yang kuat berdasarkan teori penegakan hukum sehingga dapat menjamin kepastian hukum, memberi manfaat dan keadilan bagi para pihak yang terkait (Fatoni, 2019).

Namun demikian, dalam Pelaksanaan lelang eksekusi Hak Tanggungan melalui media internet berdasarkan Undang-Undang Informasi dan Transaksi Elektronik masih terdapat beberapa permasalahan yang dapat menghambat pelaksanaan lelang. Hambatan tersebut dapat terjadi terkait dengan proses eksekusi Hak Tanggungan diantaranya Debitur adakalanya tidak 
secara sukarela menerima pelaksanaan lelang eksekusi atas objek Hak Tanggungan yang dilakukan oleh bank dikarenakan kurangnya informasi yang diberikan oleh bank terkait penyelesaian kredit. Debitur mengajukan gugatan atau perlawanan untuk menunda atau membatalkan pelaksanaan lelang eksekusi tersebut dengan alasan terkait kepemilikan objek Hak Tanggungan, harga limit objek Hak Tanggungan yang dianggap terlalu rendah, atau debitur merasa belum wanprestasi. Sedangkan hambatan terkait dengan pemrosesan permohonan lelang, diantaranya kehadiran penjual dan saksi ditempat lelang pada masa pandemi Covid 19, Pejabat lelang dan Pembeli tidak saling bertemu, serta dokumen penawaran yang dihasilkan dari hasil cetakan aplikasi lelang melalui media internet.

Pelaksanaan lelang didahului dengan adanya upaya mengumpulkan para peminat melalui pengumuman lelang. Para peserta lelang berkumpul dalam pelaksanaan lelang untuk mendapatkan harga tertinggi akan tetapi kadang kala terdapat calon pembeli/peserta lelang yang tidak mempunyai itikad baik dalam mengikuti lelang tersebut yang menyebabkan harga lelang tidak optimal. Permasalahan ini dapat diatasi dengan pelaksanaan lelang eksekusi melalui internet karena dengan penggunaan media internet tidak ada interaksi langsung diantara para peserta lelang sehingga dapat menghindari terjadinya intimidasi antar peserta lelang dan dapat menghasilkan harga lelang yang optimal.

Hambatan-hambatan dalam pelaksanaan lelang eksekusi tersebut akan mengakibatkan kerugian bagi bank sebagai kreditur karena tidak dapat memperoleh pengembalian atas kredit yang telah diberikan dan dapat menghambat peran serta masyarakat untuk ikut berpartisipasi dalam pelaksanaan lelang.

Pejabat Lelang pada KPKNL sebagai pejabat yang melaksanakan lelang bertanggung jawab atas kelancaran pelaksanaan lelang dan harus memiliki prinsip kehati-hatian dalam melaksanakan lelang sesuai dengan prosedur yang telah ditetapkan sehingga dapat mengatasi hambatan yang terjadi dalam pelaksanaan lelang dan melindungi kepentingan para pengguna jasa lelang.

Berdasarkan uraian dan permasalahan-permasalahan yang telah diuraikan di atas, dapat dirumuskan pokok permasalahan yaitu bagaimana aturan hukum, mekanisme dan hambatan yang dihadapi pada pelaksanaan lelang eksekusi Hak Tanggungan ketika Pejabat Penjual dan peserta lelang tidak hadir secara fisik dalam proses lelang dan kedudukan risalah lelang sebagai alat bukti hukum yang sah. Berkaitan dengan hal tersebut, peneliti melakukan penelitian untuk tesis ini dengan judul "Pelaksanaan Lelang Eksekusi Hak Tanggungan Melalui Media Internet Masa Pandemi Covid 19 Berdasarkan Undang-Undang Informasi dan Transaksi Elektronik (Studi Pada Kantor Pelayanan Kekayaan Negara Dan Lelang (KPKNL) Medan".

\section{METODE PENELITIAN}

Jenis penelitian yang digunakan peneliti adalah penelitian hukum yuridis normatif. Penelitian hukum yuridis normatif disebut juga sebagai penelitian hukum doktriner karena dilakukan hanya pada peraturan-peraturan tertulis atau bahan-bahan hukum yang lain atau disebut juga penelitian perpustakaan/studi dokumen karena penelitian lebih banyak dilakukan terhadap data sekunder (Bambang: 2008). Untuk melengkapi data sekunder yang diambil dari data kepustakaan (library research) maka dilakukan juga pengambilan data primer mengenai pelaksanaan lelang eksekusi Hak Tanggungan melalui media internet masa pandemi Covid 19 berdasarkan Undang-Undang informasi dan transaksi elektronik sebagai hasil dari penelitian lapangan (field research) yang dilakukan di KPKNL Medan.

Metode Pendekatan penelitian yang digunakan dalam penelitian ini adalah sebagai berikut: Pendekatan hukum historis untuk mengkaji norma dan objek hukum yang berlaku sebelumnya berkenaan dengan pelaksanaan lelang eksekusi Hak Tanggungan melalui media internet masa pandemi Covid 19 berdasarkan Undang-Undang informasi dan transaksi elektronik. Pendekatan hukum eksplanatoris untuk melihat kedalaman norma hukum dan mengkaji objek hukum berkenaan dengan pelaksanaan lelang eksekusi Hak Tanggungan melalui media internet masa 
Maryoso, Isnaini \& M. Citra Ramadhan, Pelaksanaan Lelang Eksekusi Hak Tanggungan

pandemi Covid 19 berdasarkan Undang-Undang informasi dan transaksi elektronik. Pendekatan hukum sinkronisasi untuk melihat konsistensi hubungan objek hukum dengan norma hukum berkenaan dengan pelaksanaan lelang eksekusi Hak Tanggungan melalui media internet masa pandemi Covid 19 berdasarkan Undang-Undang informasi dan transaksi elektronik.

Penelitian ini dilakukan di Kantor Pelayanan Kekayaan Negara dan Lelang (KPKNL) Medan yang beralamat di Jl. P. Diponegoro No. 30 A Medan. Data dan sumber data yang dipergunakan terdiri dari bahan hukum primer, bahan hukum sekunder dan bahan hukum tersier. Bahan Hukum Primer yang meliputi Peraturan Perundang-undangan, Bahan hukum sekunder yang digunakan adalah yang erat kaitannya dengan bahan hukum primer guna membantu menganalisis serta memahami masalah yang dikaji, yang terdiri dari buku-buku hasil pendapat para pakar/ahli, hasilhasil penelitian dan seminar atau kegiatan ilmiah lainnya seperti majalah, jurnal yang berkaitan dengan pokok persoalan, serta dokumentasi terkait. Bahan hukum tersier digunakan untuk memberikan informasi tentang bahan hukum primer dan bahan hukum sekunder misalnya kamus, ensiklopedia, dan lain-lain yang erat relevansinya dengan materi penelitian.

\section{HASIL DAN PEMBAHASAN}

Aturan Hukum Yang Mengatur Pelaksanaan Lelang Eksekusi Hak Tanggungan Melalui Media Internet Masa Pandemi Covid-19 Berdasarkan Undang-Undang Informasi dan Transaksi Elektronik

1. Dasar hukum pelaksanaan lelang di Indonesia, diatur dalam beberapa peraturan khusus yang mengatur tentang pelaksanaan lelang. Peraturan- peraturan tersebut adalah :

2. Vendu Reglement (Peraturan Lelang) Staatsblad 1908 : 189 sebagaimana telah beberapa kali diubah terakhir dengan Staatsblad 1941 : 43. Vendu Reglement mulai berlaku tangal 1 April 1908, merupakan peraturan yang mengatur prinsip-prinsip pokok tentang lelang. Bentuk peraturan ini berupa Reglement, yang dapat dianggap sederajat dengan Undang-Undang.

3. Vendu Instructie (Instruksi Lelang ) Staatsblad 1908 : 190 sebagaimana telah beberapa kali diubah terakhir dengan Staatsblad 1930 : 85. Vendu Instructie merupakan ketentuanketentuan yang melaksanakan Vendu Reglement.

4. Undang-Undang Nomor 11 tahun 2008 tentang Informasi dan Transaksi Elektronik (ITE) sebagaimana telah diubah oleh Undang-Undang Nomor 19 Tahun 2016

5. Peraturan Pemerintah Nomor 21 tahun 2020 tentang Pembatasan Sosial Berskala Besar (PSBB) pada masa Covid

6. Peraturan Pemerintah Republik Indonesia Nomor 62 tahun 2020 tentang Jenis dan Tarif Atas Jenis Penerimaan Negara Bukan Pajak yang Berlaku Pada Kementerian Keuangan.

7. Peraturan Menteri Keuangan Nomor 27/PMK.06/2016 tentang Petunjuk Pelaksanaan Lelang.

8. Peraturan Menteri Keuangan Nomor 113/PMK.06/2019 tentang Balai Lelang.

9. Peraturan Menteri Keuangan Nomor 94/PMK.06/2019 tentang Pejabat Lelang Kelas I.

10. Peraturan Menteri Keuangan Nomor 189/PMK.06/2017 tentang Pejabat Lelang Kelas II.

11. Peraturan Menteri Keuangan Nomor 90/PMK.06/2016 tentang Pedoman Pelaksanaan Lelang dengan Penawaran Secara Tertulis Tanpa Kehadiran Peserta Lelang Melalui Internet.

12. Keputusan Menteri Keuangan Nomor 119/KMK.01/2020 tentang Pedoman Pelaksanaan Rencana Keberlangsungan Layanan (Business Continuity Plan) terkait Dampak Corona Virus Disease 2019 (Covid 19) di lingkungan Kementerian Keuangan

Mekanisme Pelaksanaan Lelang Eksekusi Hak Tanggungan Melalui Media Internet Masa Pandemi Covid-19 Berdasarkan Undang-Undang Informasi dan Transaksi Elektronik

Mekanisme pelaksanaan lelang meliputi tiga tahapan, yaitu tahapan Persiapan Lelang, Pelaksanaan lelang, dan setelah pelaksanaan lelang, dengan uraian sebagai berikut:

\section{1) Persiapan Lelang}

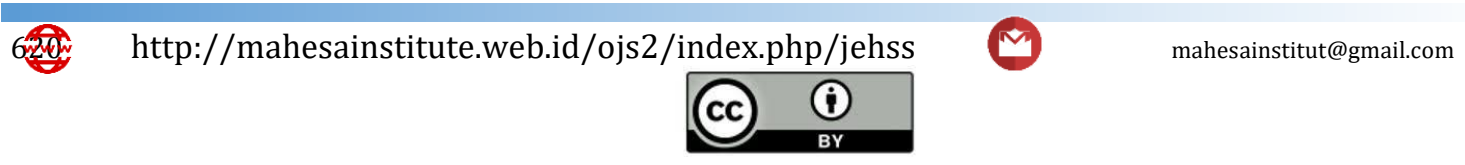

620 
Pemohon lelang yang akan melakukan penjualan barang secara lelang melalui KPKNL harus mengajukan surat permohonan lelang secara tertulis kepada Kepala KPKNL sesuai dengan wilayah kerjanya dengan disertai dokumen persyaratan lelang. Dokumen persyaratan lelang eksekusi berdasarkan Pasal 6 Undang-Undang Nomor 4 Tahun 1996 adalah:

a. Salinan/fotokopi Perjanjian Kredit;

b. Salinan/fotokopi Sertifikat Hak Tanggungan dan Akta Pemberian Hak Tanggungan;

c. Salinan/fotokopi Sertifikat Hak Atas Tanah yang dibebani Hak Tanggungan;

d. Salinan/fotokopi Perincian Hutang/Jumlah Kewajiban debitor yang harus dipenuhi;

e. Salinan/fotokopi bukti bahwa debitor wanprestasi, berupa peringatan- peringatan maupun pernyataan dari pihak kreditor;

f. Surat pernyataan dari kreditor selaku pemohon lelang yang isinya akan bertanggung jawab apabila terjadi gugatan;

g. Salinan/fotokopi surat pemberitahuan rencana pelaksanaan lelang kepada debitor oleh kreditor, yang diserahkan paling lama 1 (satu) hari sebelum lelang dilaksanakan;

Kepala KPKNL akan menetapkan jadwal pelaksanaan lelang dan menunjuk Pejabat Lelang untuk melaksanakan permohonan lelang tersebut. Pejabat Lelang wajib meneliti kelengkapan dokumen persyaratan lelang dan legalitas formal subjek dan objek lelang. Pejabat Lelang tidak boleh menolak permohonan lelang yang diajukan terhadapnya sepanjang dokumen persyaratan lelang telah memenuhi legalitas formal subjek dan objek lelang. Pejabat Lelang wajib menolak permohonan lelang yang bukan merupakan kewenangannya atau dokumen persyaratan lelang tidak lengkap atau tidak memenuhi legalitas formal subjek dan objek lelang.

Pelaksanaan lelang harus memenuhi persyaratan sebagai berikut:

a. Setiap pelaksanaan lelang harus dilakukan oleh dan/atau di hadapan Pejabat Lelang kecuali ditentukan lain oleh Undang-Undang atau Peraturan Pemerintah.

b. Dilaksanakan secara terbuka yang dihadiri oleh Penjual dan Peserta Lelang. Lelang tetap dapat dilaksanakan walaupun hanya diikuti oleh satu orang peserta lelang. Bilamana tidak ada peserta lelang, lelang tetap dilaksanakan dan dibuatkan Risalah Lelang Tidak Ada Penawaran.

c. Lelang dilaksanakan pada hari dan jam kerja yang telah ditentukan dan bertempat dalam wilayah kerja KPKNL tempat barang berada.

d. Adanya uang jaminan penawaran yang disetorkan ke KPKNL oleh calon peserta lelang sebelum pelaksanaan lelang minimal $20 \%$ dari nilai limit dan maksimal $50 \%$ dari nilai limit.

e. Adanya nilai limit, yaitu harga minimal barang yang akan dlelang dan ditetapkan oleh Penjual/Pemilik Barang.

f. Pelaksanaan lelang didahului dengan pengumuman lelang.

g. Penjual atau Pemilik Barang wajib memperlihatkan atau menyerahkan asli dokumen kepemilikan kepada Pejabat Lelang kecuali terhadap lelang eksekusi yang menurut peraturan perundang-undangan tetap dapat dilaksanakan walaupun dokumen kepemilikannya tidak dikuasai. Bilamana Penjual tidak menyerahkan asli dokumen kepemilikan kepada Pejabat Lelang, Penjual wajib memperlihatkan kepada Peserta Lelang sebelum lelang dimulai.

h. Pembayaran harga lelang dan bea lelang dilakukan secara tunai (cash) atau giro paling lambat 5 (lima) hari kerja setelah pelaksanaan lelang.

i. Pelaksanaan lelang wajib dituangkan dalam Berita Acara yang disebut Risalah Lelang.

Pasal 52 Peraturan Menteri Keuangan Nomor 27/PMK.06/ 2016 tentang Petunjuk Pelaksanaan Lelang mensyaratkan bahwa pelaksanaan lelang didahului adanya Pengumuman Lelang. Pengumuman Lelang adalah pemberitahuan kepada masyarakat tentang akan adanya lelang dengan maksud untuk menghimpun peminat lelang dan pemberitahuan kepada pihak yang berkepentingan. Pengumuman Lelang paling sedikit memuat:

a. Identitas Penjual;

b. Hari, tanggal, waktu dan tempat pelaksanaan lelang dilaksanakan;

c. Jenis dan jumlah barang; 
Maryoso, Isnaini \& M. Citra Ramadhan, Pelaksanaan Lelang Eksekusi Hak Tanggungan

d. Lokasi, luas tanah, jenis hak atas tanah, dan ada atau tidak ada bangunan, khusus untuk barang tidak bergerak berupa tanah dan/atau bangunan;

e. Spesifikasi barang, khusus untuk barang bergerak;

f. Waktu dan tempat aanwijzing, dalam hal Penjual melakukan aanwijzing;

g. Jaminan penawaran lelang, meliputi besaran, jangka waktu, cara dan tempat penyetoran, dalam hal dipersyaratkan adanya jaminan penawaran lelang;

h. Nilai limit, kecuali lelang kayu dan Hasil Hutan Lainnya dari tangan pertama dan lelang non eksekusi sukarela untuk barang bergerak;

i. Jangka waktu kewajiban pembayaran lelang oleh Pembeli;

j. Alamat domain KPKNL yang melaksanakan lelang dengan penawaran lelang melalui internet atau alamat surat elektronik KPKNL yang melaksanakan lelang dengan penawaran lelang melalui surat elektronik;

k. Syarat tambahan dari Penjual (apabila ada).

Pengumuman lelang dilaksanakan melalui surat kabar harian yang terbit dan/atau beredar di kota atau kabupaten tempat barang berada. Surat kabar tersebut harus mempunyai tiras/oplah sebagai berikut:

a. Paling rendah 5.000 (lima ribu) eksemplar jika dilakukan dengan surat kabar harian yang terbit di kota atau kabupaten;

b. Paling rendah 15.000 (lima belas ribu) eksemplar jika dilakukan dengan surat kabar harian yang terbit di ibukota propinsi;

c. Paling rendah 20.000 (dua puluh ribu) eksemplar jika dilakukan dengan surat kabar harian yang terbit di ibukota negara.

Pengumuman lelang untuk lelang eksekusi terhadap barang tidak bergerak atau barang tidak bergerak yang dijual bersama-sama barang bergerak dilakukan dengan ketentuan sebagai berikut:

a. Pengumuman dilakukan 2 (dua) kali dengan jangka waktu pengumuman lelang pertama ke pengumuman lelang kedua adalah 15 hari kalender dan diatur sedemikian rupa agar pengumuman lelang kedua tidak jatuh pada hari libur.

b. Pengumuman pertama dapat dilakukan melalui selebaran, tempelan yang mudah dibaca oleh umum dan atau melalui media elektronik termasuk internet, namun demikian dalam hal dikehendaki oleh Penjual dapat dilakukan melalui surat kabar harian.

c. Pengumuman lelang kedua harus dilakukan melalui surat kabar harian dan dilakukan paling singkat 14 (empat belas) hari kalender sebelum pelaksanaan lelang.

Pada umumnya objek lelang eksekusi Hak Tanggungan berupa tanah atau tanah dan bangunan. Dalam pelaksanaan lelang berupa tanah, sebelum pelaksanaan lelang disyaratkan adanya Surat Keterangan Tanah (SKT). Ketentuan mengenai Surat Keterangan Tanah adalah:

a. Pelaksanaan lelang atas tanah atau tanah dan bangunan wajib dilengkapi dengan Surat Keterangan Tanah (SKT) dari Kantor Pertanahan setempat.

b. Permintaan penerbitan Surat Keterangan Tanah (SKT) kepada Kepala Kantor Pertanahan setempat diajukan oleh Kepala KPKNL.

c. Dalam hal tanah atau tanah dan bangunan yang akan dilelang belum terdaftar di Kantor Pertanahan setempat, Kepala KPKNL mensyaratkan kepada Penjual untuk meminta Surat Keterangan dari Lurah atau Kepala Desa yang menerangkan status kepemilikan. Berdasarkan Surat Keterangan tersebut, Kepala KPKNL meminta Surat Keterangan Tanah (SKT) ke Kantor Pertanahan setempat.

d. Dalam hal dokumen kepemilikan tidak dikuasai oleh Penjual, setiap dilaksanakan lelang harus dimintakan Surat Keterangan Tanah (SKT) baru.

Berdasarkan ketentuan dalam Pasal 43 Peraturan Menteri Keuangan Nomor 27/PMK.06/ 2016, tentang Petunjuk Pelaksanaan Lelang, setiap pelaksanaan lelang dipersya-ratkan adanya Nilai Limit Lelang. Nilai limit lelang adalah harga minimal barang yang akan dilelang dan ditetapkan oleh Penjual. Penjual menetapkan nilai limit berdasarkan penilaian oleh penilai atau penaksiran oleh penaksir. Penetapan nilai limit menjadi tanggung jawab Penjual dan bukan 
tanggung jawab Pejabat Lelang. Nilai Limit lelang untuk kepentingan eksekusi berdasarkan pasal 6 Undang-Undang Hak Tanggungan harus ditetapkan oleh Penjual berdasarkan hasil penilaian dari Penilai. Penilai merupakan pihak yang melakukan penilaian secara independen berdasarkan kompetensi yang dimilikinya. Nilai limit dibuat secara tertulis oleh Penjual dan diserahkan kepada Pejabat Lelang paling lambat sebelum pengumuman lelang atau sebelum lelang dimulai dalam hal nilai limit tidak dicantumkan dalam pengumuman lelang. Nilai limit dalam pelaksanaan lelang eksekusi berdasarkan pasal 6 Undang-Undang Nomor 4 Tahun 1996 ditetapkan paling sedikit sama dengan Nilai Likuidasi. Masa berlaku laporan penilaian untuk lelang eksekusi dalam rangka pasal 6 Undang-Undang Nomor 4 Tahun 1996 berlaku untuk jangka waktu paling lama 12 (dua belas) bulan sejak tanggal penilaian sampai dengan pelaksanaan lelang kecuali terdapat perubahan kondisi yang signifikan menurut Penjual.

\section{2) Pelaksanaan Lelang}

a. Pelaksanaan lelang terdiri dari kegiatan penentuan peserta lelang, penyerahan nilai limit, pelaksanaan penawaran lelang, dan penunjukan pembeli. Hal-hal yang harus diperhatikan dalam pelaksanaan lelang adalah:

b. Pejabat Lelang harus mengecek keabsahan peserta lelang/kuasanya dan bukti setoran uang jaminan.

c. Pejabat Lelang memimpin lelang dengan memulai pembacaan kepala Risalah Lelang dan diikuti dengan tanya jawab tentang pelaksanaan lelang antara peserta lelang, pejabat penjual dan pejabat lelang. Pertanyaan mengenai barang akan dijawab oleh Pejabat Penjual dan pertanyaan mengenai prosedur lelang akan dijawab oleh Pejabat Lelang.

d. Peserta lelang mengajukan penawaran lelang. Penawaran lelang secara tertulis tanpa kehadiran peserta lelang dilakukan melalui surat elektronik (email), melalui surat tromol pos atau melalui internet baik cara terbuka (open bidding) maupun cara tertutup (closed bidding). Penawaran lelang melalui surat elektronik, tromol pos atau internet cara tertutup (closed bidding) dibuka pada saat pelaksanaan lelang oleh Pejabat Lelang bersama dengan 2 (dua) orang saksi, masing-masing 1 (satu) orang dari KPKNL dan 1 (satu) orang dari penjual.

e. Peserta lelang wajib melakukan penawaran paling sedikit sama dengan nilai limit

f. Penunjukan pembeli oleh Pejabat Lelang dilakukan terhadap peserta lelang yang mengajukan harga penawaran tertinggi mencapai atau melampaui nilai limit yang telah ditentukan.

Pelaksanaan Lelang melalui internet atau E-auction dilakukan melalui aplikasi berbasis internet melalui browser pada alamat https://www.lelang.go.id. Aplikasi tersebut dapat diakses melalui komputer, laptop, maupun telepon pintar berbasis android sehingga peserta lelang dapat mengikuti lelang dimanapun dia berada.

Pelaksanaan lelang melalui internet dapat dilakukan dengan dua cara penawaran yaitu penawaran tertutup (closed bidding) dan penawaran terbuka (open bidding) (Sasongko, 2017). Penawaran tertutup (closed bidding) merupakan penawaran yang disampaikan oleh Peserta Lelang yang hanya dapat diketahui oleh Peserta Lelang lainnya setelah daftar penawaran dibuka oleh Pejabat Lelang sedangkan penawaran terbuka (open bidding) merupakan penawaran yang disampaikan oleh Peserta Lelang yang dapat diketahui oleh Peserta Lelang lainnya yang telah menyampaikan penawaran. Penawar dengan harta tertinggi akan ditetapkan oleh Pejabat Lelang sebagai pemenang lelang.

\section{3) Setelah Pelaksanaan Lelang}

Proses setelah pelaksanaan lelang yaitu peserta lelang yang mengajukan harga penawaran tertinggi ditunjuk sebegai pemenang lelang oleh Pejabat Lelang. Pemenang lelang wajib melakukan pembayaran harga lelang berikut biaya-biaya lainnya yang telah ditetapkan sesuai peraturan. Peraturan Pemerintah Republik Indonesia Nomor 62 tahun 2020 tentang Jenis dan Tarif Atas Jenis Penerimaan Negara Bukan Pajak yang Berlaku Pada Kementerian Keuangan 
Maryoso, Isnaini \& M. Citra Ramadhan, Pelaksanaan Lelang Eksekusi Hak Tanggungan

mengatur tentang jenis dan tarif penerimaan negara bukan pajak yang dari pelaksanaan lelang eksekusi berdasarkan pasal 6 Undang-Undang Nomor 4 Tahun 1996

Pembayaran harga lelang dilakukan secara tunai (cash) atau cek atau giro paling lambat 5 (lima) hari kerja setelah pelaksanaan lelang. Setelah menerima pembayaran lelang, Pejabat Lelang menyetorkan hasil lelang yang terdiri dari hasil bersih kepada Penjual dan Bea Lelang serta Pajak Penghasilan disetorkan ke Kas Negara. Hasil bersih lelang adalah pokok lelang yang telah dikurangi bea lelang penjual dan/atau Pajak Penghasilan atas penghasilan dari pengalihan hak atas tanah dan/atau bangunan (PPh final).

Pejabat Lelang membuat Risalah Lelang sebagai berita acara pelaksanaan lelang, yang terdiri dari minuta, salinan, dan kutipan risalah lelang. Risalah Lelang merupakan berita acara pelaksanaan lelang yang mencatat segala peristiwa yang terjadi pada saat penjualan lelang. Menurut Peraturan Menteri Keuangan Nomor 27/PMK.06/2016 tentang Petunjuk Pelaksanaan Lelang, Risalah lelang adalah berita acara pelaksanaan lelang yang merupakan akta otentik dan mempunyai kekuatan pembuktian sempurna. Minuta Risalah Lelang merupakan asli risalah lelang berikut lampirannya yang merupakan dokumen atau arsip negara dan disimpan di KPKNL. Salinan Risalah Lelang adalah salinan kata demi kata dari seluruh Risalah Lelang dan diberikan kepada Penjual dan Kantor Wilayah sebagai laporan pelaksanaan lelang. Kutipan Risalah Lelang adalah kutipan kata demi kata dari satu atau beberapa bagian Risalah Lelang dan diberikan kepada pembeli lelang sebagai bukti berita acara pelaksanaan lelang dan dasar perolehan hak oleh pembeli. Pembeli dapat memperoleh kutipan apabila telah membayar Bea Perolehan Atas Tanah dan (Bangunan (BPHTB). Uang jaminan peserta lelang yang tidak ditunjuk menjadi pemenang akan dikembalikan kepada peserta lelang yang bersangkutan.

Tahap selanjutnya adalah penyerahan dokumen kepemilikan lelang. Pejabat Lelang/Penjual harus menyerahkan asli dokumen kepemilikan kepada Pembeli paling lambat 1 (satu) hari kerja setelah Pembeli menunjukkan kuitansi atau tanda bukti pelunasan pembayaran dan menyerahkan bukti setor Bea Perolehan Hak Atas Tanah dan atau Bangunan (BPHTB) jika objek lelang berupa tanah dan atau bangunan.

KPKNL Medan dalam pelaksanaan lelang melalui internet bertindak selaku penyelenggara sistem elektronik sudah memperhatikan dan memenuhi syarat-syarat sebagai penyelenggara sistem elektronik sebagaimana ditentukan dalam Undang-Undang Nomor 11 Tahun 2008 tentang Informasi dan Transaksi Elektronik sebagaimana telah diubah oleh Undang-Undang Nomor 19 Tahun 2016 tentang Perubahan Atas Undang-Undang Nomor 11 Tahun 2008 tentang Informasi Dan Transaksi Elektronik (Yahya:2009). Aplikasi E-Auction yang digunakan dalam pelaksanaan lelang melalui internet menampilkan secara utuh informasi atau dokumen mengenai objek lelang yang dibutuhkan oleh calon peserta lelang. Setiap calon peserta lelang dapat mengakses aplikasi tersebut dan terjaga kerahasiaannya dalam melakukan penawaran lelang. Aplikasi E-Auction dilengkapi dengan prosedur dan petunjuk dengan bahasa yang mudah dipahami oleh pengguna jasa lelang.

\section{Hambatan Yang Dihadapi dalam Pelaksanaan Lelang Eksekusi Hak Tanggungan Melalui Media Internet Masa Pandemi Covid-19 Berdasarkan Undang-Undang Informasi dan Transaksi Elektronik}

Berdasarkan data hasil penelitian yang diperoleh dari KPKNL Medan, beberapa hambatan yang dihadapi dalam pelaksanaan lelang melalui media internet untuk kepentingan eksekusi Hak Tanggungan berdasarkan Undang-Undang ITE pada KPKNL Medan dianalisis dengan menggunakan Teori Penegakan Hukum terdapat faktor penyebab yang mempengaruhi penegakan hukum tersebut antara lain :

\section{1) Faktor Hukum/Aturan yang ada yaitu :}

a) Simplifikasi/Penyederhanaan Peraturan lelang

Peraturan lelang masih menggunakan peraturan warisan Belanda yang hingga kini masih berlaku adalah Vendu Reglement, suatu Ordonantie bertanggal 28 Februari 1908 yang

62 http://mahesainstitute.web.id/ojs2/index.php/jehss

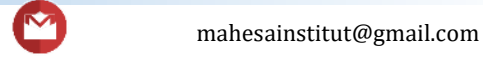

624 
mengatur tentang lelang. Undang-undang lelang warisan Belanda ini banyak isinya yang sudah tidak dapat mengakomodasi perkembangan zaman. Pasal dari Vendu Reglement ini sudah banyak yang dicabut, beberapa pasalnya tidak aplikatif lagi, ruang lingkupnya terbatas pada penjualan, dan ruang lingkup objek lelang terbatas pada barang berwujud. Salah satu wujud ketertinggalan Vendu Reglement adalah ketiadaan pengaturan lelang berbasis internet. Padahal saat ini proses lelang secara elektronik sudah berkembang. Proses lelang tanpa harus ramai-ramai dihadiri calon pembeli sudah bisa diterapkan. Pada saat ini aturan pelaksanaan lelang dilaksanakan berdasarkan Peraturan Menteri Keuangan Nomor : 27/ PMK.06/2016 tentang Petunjuk Pelaksanaan Lelang dan Peraturan Menteri Keuangan Nomor: 90/PMK.06/2016 tanggal 01 Juni 2016 tentang Pedoman Pelaksanaan Lelang Dengan Penawaran Secara Tertulis Tanpa Kehadiran Peserta Lelang Melalui Internet sebagai dasar hukum pelaksanaan lelang.

b) Terbatasnya pertemuan secara fisik dalam pelaksanaan lelang Undang-undang Nomor 6 Tahun 2018 tentang Kekarantinaan Kesehatan, beserta turunannya yaitu Keputusan Presiden Nomor 11 Tahun 2020 tentang Penetapan Kedaruratan Kesehatan Masyarakat Corona Virus Disease 2019 (Covid-19) dan PERPPU 1 Tahun 2020 tentang Kebijakan Keuangan Negara dan Stabilitas Sistem Keuangan untuk penanganan Pandemi Covid -19 dan/atau dalam rangka menghadapi ancaman yang membahayakan pereko-nomian nasional/sistem keuangan, kehadiran fisik pada saat pelaksanaan lelang antara Pihak Penjual, Peserta, Pejabat Lelang, serta saksi dapat dikesampingkan. Pelaksanaan lelang secara elektronik seyogyanya tidak berdampak apa pun terhadap keabsahan pelaksanaan lelang. Kehadiran secara audio visual telah dianggap sebagai kehadiran langsung jika merujuk pada Peraturan Mahkamah Agung Nomor 1 Tahun 2016 tentang Prosedur Mediasi di Pengadilan. Hal ini sebagai acuan bahwa kehadiran audio visual maupun telekonferensi dapat dipersamakan kehadiran fisik serta dapat dijadikan pertimbangan dan penguatan penyelenggaraan pelaksanaan lelang Eksekusi Hak Tanggungan melalui Media Internet. Secara legalitas, pelaksanaan lelang secara elektronik telah diterima dalam sistem hukum nasional dan keberadaan informasi elektronik diakui sebagai alat bukti yang sah dikaitkan dengan Undang-undang ITE.

c) Risalah lelang merupakan alat bukti hukum yang sah

Lelang merupakan mekanisme jual beli khusus dimana pelaksanaan lelang dilakukan oleh dan/atau dihadapan pejabat lelang. Pejabat lelang merupakan penengah sekaligus yang menjembatani transaksi jual beli antara penjual dan pembeli dalam lelang.

Risalah lelang dibuat sesuai aturan yang ditetapkan yang disesuaikan dengan fungsinya. Fungsi dari risalah lelang adalah sebagai alat bukti berkekuatan hukum sempurna yang memberikan alas hak dan perlindungan hukum atas jual beli barang dalam lelang. Risalah lelang juga merupakan akta otentik karena dibuat oleh pegawai yang berwenang membuatnya. Risalah lelang dibuat dalam Bahasa Indonesia dan diberi nomor urut. Sebagai akta otentik, risalah lelang menjadi bukti yang cukup untuk membuktikan bahwa perbuatan hukum yang dicantumkan atau disebutkan dalam risalah lelang merupakan perbuatan yang nyata-nyata terjadi. Sebagai bukti sempurna risalah lelang menjadi alat 
Maryoso, Isnaini \& M. Citra Ramadhan, Pelaksanaan Lelang Eksekusi Hak Tanggungan

bukti hukum yang sah untuk membuktikan perbuatan hukum yang dicantumkan atau disebutkan dalam risalah lelang, sehingga tidak diperlukan bukti-bukti yang lain.

\section{2) Faktor Masyarakat}

a) Adanya keengganan dari para pengguna jasa lelang terhadap pelaksanaan lelang melalui internet

Seiring dengan perkembangan teknologi yang semakin pesat, pelaksanaan lelang dilaksanakan dengan melalui internet. Hal ini menyebabkan masih banyaknya masyarakat yang belum mengetahui/ memahami mekanisme proses lelang melalui internet. Penulis menganalisis bahwa pelaksanaan lelang melalui media internet merupakan suatu terobosan baru yang dilaksanakan oleh Kantor Pelayanan Kekayaan Negara dan Lelang (KPKNL) untuk lebih meningkatkan pelayanan terhadap para pengguna jasa lelang dan menyesuaikan dengan perkembangan teknologi informasi yang sudah pesat pada saat ini. Pada tahap awal pengenalan pelaksanaan lelang melalui internet masih terdapat adanya keengganan/ resistensi dari para pengguna jasa lelang karena selama ini terbiasa dengan pelaksanaan lelang secara konvensional yaitu dengan kehadiran peserta lelang dan mereka belum memahami mekanisme lelang melalui internet. Hal ini wajar dialami oleh sesuatu hal yang baru diperkenalkan kepada masyarakat.

b) Objek Hak Tanggungan yang akan dilelang masih dihuni

Objek Hak Tanggungan yang akan dilelang masih dihuni baik oleh debitur maupun pihak ketiga akan menyurutkan minat calon pembeli lelang karena menimbulkan kekhawatiran dalam penguasaan fisik objek lelang setelah lelang dilaksanakan. Hal ini dapat menjadi hambatan dalam pelaksanaan lelang dan menyebabkan lelang tidak ada peminat. Berdasarkan penelitian yang dilakukan di KPKNL Medan, objek Hak Tanggungan yang masih dihuni merupakan salah satu penyebab lelang tersebut tidak ada peminat sehingga tidak laku terjual.

\section{3) Faktor Penegak Hukum}

Pejabat lelang adalah orang yang berdasarkan peraturan perundang-undangan diberi wewenang khusus untuk melaksanakan penjualan barang secara lelang. KPKNL sebagai pihak penyelenggara pelelangan objek Hak Tanggungan secara online yang dalam hal ini diwakili oleh pejabat lelang di dalam pelaksanaan lelangan akan dilindungi oleh undangundang selama prosedur yang dijalankan menurut ketentuan yang berlaku. Dalam risalah lelang, ada klausul yang menyatakan bahwa Pejabat Lelang/KPKNL tidak menanggung atas kebenaran keterangan-keterangan tentang keadaan sesungguhnya dan keadaan hukum atas barang yang dilelang tersebut, seperti luasnya, batas-batasnya, perjanjian sewa menyewa dan semuanya menjadi resiko pembeli. Penawar/Pembeli dianggap sunguhsungguh telah mengetahui apa yang telah ditawar olehnya. Apabila terdapat kekurangan/ kerusakan baik yang terlihat ataupun yang tidak terlihat, maka Penawar/Pembeli tidak berhak untuk menolak atau menarik diri kembali setelah pembelian disahkan dan melepaskan segala hak untuk meminta kerugian atas sesuatu apapun juga. Terkait hal ini, perlu digaris bawahi KPKNL sebagai penyelenggara lelang Hak Tanggungan secara online tidak bisa melaksanakan pelelangan atas tanah atau tanah dan bangunan tanpa adanya Surat Keterangan Pendaftaran Tanah (SKPT) yang diterbitkan oleh BPN. Hal tersebutlah 
yang menjadi dasar KPKNL tidak bertanggung jawab terkait objek Hak Tanggungan, dikarenakan telah ada lembaga lain yang menguji dengan bukti SKPT.

4) Faktor Sarana dan Fasilitas terkait jaringan internet, sumber listrik dan server lelang Pelaksanaan lelang eksekusi Hak Tanggungan berdasarkan Undang-Undang ITE harus didukung oleh jaringan internet, sumber listrik, dan server yang stabil. Peranannya sangat penting karena semua tahapan/ prosedur dalam pelaksanaan lelang dilaksanakan secara online melalui aplikasi lelang. Waktu yang dipakai sebagai pedoman dalam pelaksanaan lelang adalah waktu yang tercantum dalam server sehingga sangat penting dalam penentuan saat penetapan pembeli lelang.

Hambatan yang dialami di KPKNL Medan terkait jaringan internet adalah pada saat server sibuk akibat banyaknya pihak yang menggunakan aplikasi lelang internet, Pejabat Lelang mengalami kesulitan untuk mengunggah dokumen-dokumen lelang, seperti pengumuman lelang, foto objek lelang, dan kepala Risalah Lelang maupun pengesahan peserta lelang berikut pengesahan dokumen-dokumen yang diupload oleh peserta lelang. Kendala lain dirasakan oleh peserta lelang yang sulit untuk mengakses aplikasi lelang internet sehingga tidak dapat melakukan penawaran.

\section{KESIMPULAN}

Berdasarkan analisis data dan pembahasan hasil penelitian, maka dapat disimpulkan bahwa Aturan hukum pelaksanaan lelang eksekusi Hak Tanggungan melalui media internet masa pandemi Covid 19 berdasarkan undang-undang informasi dan transaksi elektronik diatur dalam Vendu Reglement (Peraturan Lelang) (Stbl. Tahun 1908 Nomor 189), Peraturan Menteri Keuangan Nomor : 27/PMK.06/2016 tentang Petunjuk Pelaksanaan Lelang dan Peraturan Menteri Keuangan Nomor 90/PMK.06/ 2016 tentang Pedoman Pelaksanaan Lelang Dengan Penawaran Secara Tertulis Tanpa Kehadiran Peserta Lelang Melalui Internet dan Keputusan Menteri Keuangan Nomor 119/KMK.01/2020 tentang Pedoman Pelaksanaan Rencana Keberlangsungan Layanan (Business Continuity Plan) terkait Dampak Pandemi Covid 19 di lingkungan Kementerian Keuangan. Mekanisme pelaksanaan lelang eksekusi Hak Tanggungan melalui media internet masa pandemi Covid 19 berdasarkan undang-undang informasi dan transaksi elektronik dilaksa-nakan tanpa kehadiran fisik/pertemuan penjual, peserta lelang, dan pejabat lelang. Penawaran lelang dilakukan melalui internet baik cara terbuka (open bidding) maupun cara tertutup (closed bidding). Kedudukan risalah lelang sebagai akta otentik merupakan alat bukti hukum yang sah. Hambatan pelaksanaan lelang eksekusi Hak Tanggungan melalui media internet berdasarkan undang-undang informasi dan transaksi elektronik pada KPKNL Medan masih perlu diupayakan perbaikan-perbaikan baik dari segi peraturan maupun sarana pendukungnya sehingga pelaksanaan lelang dapat memberikan keadilan, kepastian hukum dan memberikan kemanfaatan bagi masyarakat khususnya dalam meningkatkan pertumbuhan pembangunan ekonomi. 


\section{DAFTAR PUSTAKA}

Amalia, D. F. (2019). Perlindungan Hukum Bagi Pemenang Lelang Apabila Obyek Lelang Disita Dalam Perkara Pidana. Fairness and Justice: Jurnal Ilmiah Ilmu Hukum, 17(1), 18-35.

Fatoni, M. F. (2019). WEWENANG TIM PENILAI (APPRAISAL) DALAM MENENTUKAN NILAI LIMIT LELANG HAK TANGGUNGAN. Negara Dan Keadilan, 8(1).

Ferry, Elvinawanty, R, \& Manurung, Y.S. (2019). Kecanduan Internet ditinjau dari Kecerdasan Emosi. Journal of Education, Humaniora and Social Sciences (JEHSS). 2 (1): 47 - 54.

Marliyana, E. (2019). Pelaksanaan Perjanjian Pinjam Meminjam Uang Dengan Jaminan Benda Bergerak Berdasarkan Undang-Undang Nomor 42 Tahun 1999 Tentang Jaminan Fidusia Di PT Pegadaian (Persero) Cabang Subang. Universitas Islam Sultan Agung.

Manan, Abdul, 2004, Peranan Hukum dalam Pembangunan Ekonomi, Jakarta: Kencana Prenada Media Grup

Muchlis, M. (n.d.). PERAN BANK SYARIAH SEBAGAI PENOPANG EKONOMI DI MASA NEW NORMAL. PROBLEMATIKA EKONOMI DAN PANDEMI COVID-19.

Risa, Y. (2017). Perlindungan Hukum Terhadap Kreditur Atas Wanprestasi Debitur Pada Perjanjian Kredit Dengan Jaminan Hak Tanggungan. Normative Jurnal Ilmiah Hukum, 5(2 November), 78-93.

Saifudin, B. (2019). Perlindungan Hukum Kepada Konsumen dalam Perdagangan Transaksi Elektronik $\begin{array}{lllll}\text { Berbasis Online. DOKTRINA: JOURNAL OF LAW, 2(2), 135-150. } & \text {. }\end{array}$ doi:https://doi.org/10.31289/doktrina.v2i2.2616

Sasongko, T. I. (2017). Kewenangan Notaris Dalam Pembuatan Akta Risalah Lelang Pasca Berlakunya Peraturan Menteri Keuangan Nomor 90/PMK. 06/2016 Tentang Pedoman Pelaksanaan Lelang Dengan Penawaran Secara Tertulis Tanpa Kehadiran Peserta Lelang Melaui Internet. Universitas Islam Indonesia.

Subekti, 2005, Hukum Perjanjian, Jakarta: PT Intermasa

Sulastri, L. (2016). Konstruksi Perlindungan Hukum Debitur dalam Penyelesaian Kredit Bermasalah dengan Pelaksanaan Lelang Jaminan Hak Tanggungan. Jurnal Pembaharuan Hukum, 2(1), 86-101.

Waluyo, Bambang, 2008, Penelitian Hukum dalam Praktek, Jakarta: Sinar Grafika

Wijaya, E., Fendy, F., \& Aisyah, A. (2020). Yuridis Pemberian Kredit Bank dengan Jaminan Hak Tanggungan pada PT. Bank Mestika Dharma, Medan. Journal of Education, Humaniora and Social Sciences (JEHSS), 3(2), 412-418. doi:https://doi.org/10.34007/jehss.v3i2.322

Yahya Ahmad Zein, 2009, Kontrak Elektronik dan Penyelesaian Sengketa Bisnis E Commerce dalam Transaksi Nasional dan Internasional, Bandung: CV Mandar Maju

Zaki, B. F. (2016). Kepastian Hukum Dalam Pelelangan Objek Hak Tanggungan Secara Online. Fiat Justisia: Jurnal Ilmu Hukum, 10(2).

Peraturan Pemerintah Nomor 82 tahun 2012 tentang Penyelenggaraan Sistem dan Transaksi Elektronik

Peraturan Menteri Keuangan Nomor 27/PMK.06/2016 tentang Petunjuk Pelaksanaan Lelang

Peraturan Menteri Keuangan Nomor 90/PMK. 06/ 2016 tentang Pedoman Pelaksanaan Lelang dengan Penawaran Secara Tertulis Tanpa Kehadiran Peserta Lelang Melalui Internet

Peraturan Menteri Keuangan No.113/PMK.06/2019 tentang Balai Lelang

Peraturan Menteri Keuangan No. 94/PMK.06/2019 tentang Pejabat Lelang

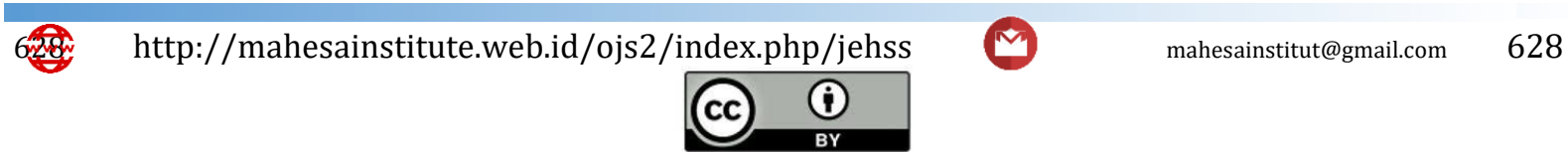

This work is licensed under a Creative Commons Attribution 4.0 